\title{
Histoplasmosis
}

\section{A review, and account of three patients diagnosed in Great Britain}

\author{
W. M. MACLEOD, I. G. MURRAY ${ }^{1}$, JEAN DAVIDSON, \\ and D. D. G IB B S ${ }^{2}$
}

Southampton University Western (Chest) Hospital, Oakley Road, Southampton

\begin{abstract}
Active histoplasmosis is rarely diagnosed in Great Britain. We present the illness records of three patients with disseminated histoplasmosis. In two patients the infection was discovered at necropsy and resulted in caseous destruction of the adrenal glands, and in one of these there was also fungal invasion of the liver and wall of the aorta. The third patient had Addison's disease and also a chronic tongue ulcer from which the fungus was cultured by biopsy.

The eight other patients with disseminated histoplasmosis and the six with active localized disease previously reported in Great Britain are reviewed.

The natural history of the disease, with emphasis on the prolonged incubation period of up to 18 years, is described. Granulomatous ulceration of the oropharynx and larynx and caseous destruction of the adrenal glands may be characteristic features.

Diagnosis usually requires a history of a stay in endemic regions. It is suggested by the clinical picture and positive complement fixation or precipitin tests and it is confirmed by culture of the fungus which may also be recognized in histological preparations. Histoplasmin skin tests are usually negative.

Standard treatment is with intravenous amphotericin B, but in our surviving patient a chronic tongue ulcer of nine years' duration showed considerable healing after 10 months' oral treatment with trimethoprim-sulphamethoxazole in combination.
\end{abstract}

Histoplasmosis was first recognized and named as a separate disease by Dr. Samuel Darling while investigating leishmania infections in the Canal Zone of Panama (Darling, 1906, 1908). Although the Americas still show the highest incidence of the disease, infected patients have been found in the Far East, Africa, and the Mediterranean regions. In Europe, the disease is still rare and in Great Britain infection by the fungus Histoplasma capsulatum is almost unknown. Less rarely, the disease, following infection abroad, is first recognized in this country at necropsy. We record the histories of two such patients and of a third patient in whom active disseminated histoplasmosis was diagnosed in England during life.

\section{CASE REPORTS}

CASE 1 P.S. was a regular army officer born on 23 January 1921. He had served abroad in Europe, Burma, Java, and Malaya. In 1955 he was invalided

1Dr. I. G. Murray died on 26 July, 1971

2Present address: Good Hope General Hospital, Sutton Coldficld, Warwickshire home with presumed pulmonary tuberculosis. His chest radiograph showed mottling with some calcifica- 흔 tion, but no cavitation, in the right upper lobe. Sputum was negative on microscopy and on culture for Mycobacterium tuberculosis. After four months' treatment with streptomycin and isoniazid, resection of the right upper lobe was performed. Direct smear from the operative specimen showed scanty acid-fast bacilli but cultures were negative.

In March 1961, during a febrile illness, the chest radiograph again showed mottling in the right upper lung (Fig. 1). Treatment with streptomycin and isoniazid was resumed. In July he developed anorexia, o loss of weight, and skin pigmentation. His blood $N$ pressure was $80 / 60 \mathrm{mmHg}$. The liver and spleen $\mathcal{N}$ were palpable. Plasma sodium was $122 \mathrm{mEq} / \mathrm{l}$ and $\mathrm{\omega}$ urine 17 -ketosteroids $2 \cdot 2 \mathrm{mg} /$ day. The Thorn test was positive. A diagnosis of Addison's disease was made 0 and he was treated with cortisone, $75 \mathrm{mg}$ daily.

It was at this time that he first noticed a painful $\mathscr{D}$ ulcer on the left side of the tongue. Biopsy of the ulcer showed chronic inflammatory granulation tissue with numerous giant cells but no caseation. Acid-fast bacilli were not seen but the appearances were thought to be compatible with active tuberculosis.

In January 1965 he was first admitted to Southampton Chest Hospital. His main complaint was still that 


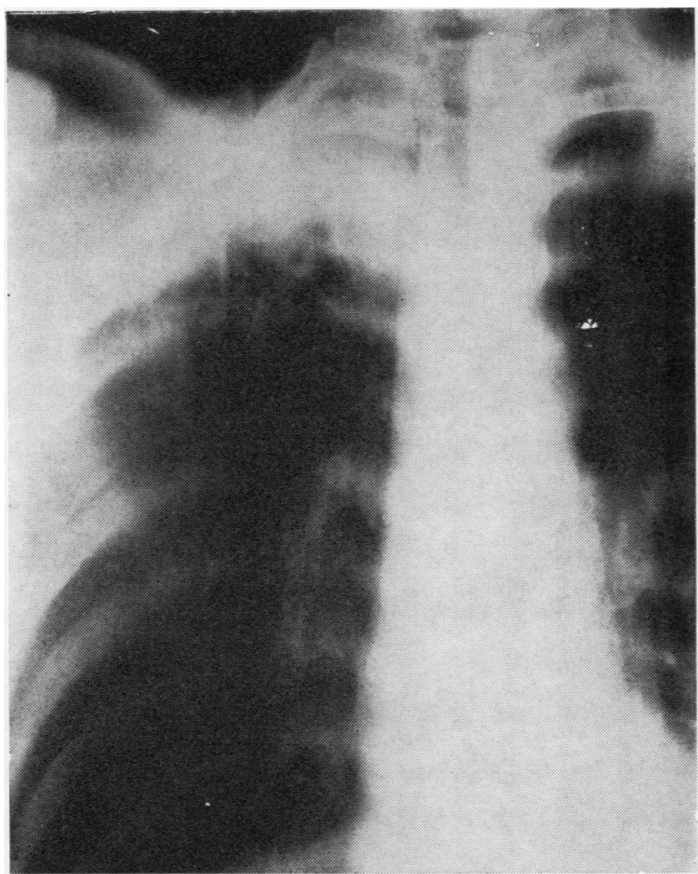

FIG. 1. Case 1. 1961. Tomogram, $5 \mathrm{~cm}$ posterior cut, showing pleural 'cap' overlying mottling in right upper lung.

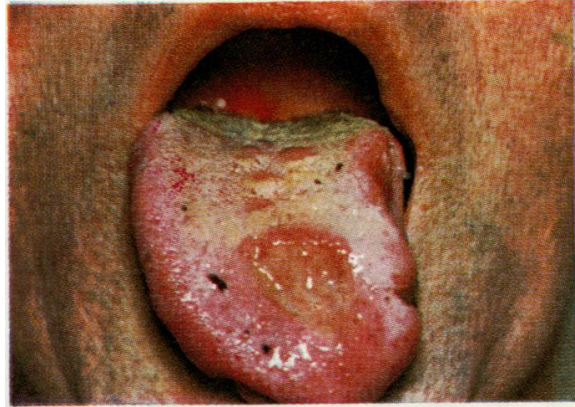

FIG. 2. Case 1. 1965. Superior view of tongue showing ulceration on dorsum and deformity of left margin.

of tongue ulceration which had slowly progressed over four years. The tongue showed irregular granulomatous ulceration from the left side round under the tip to the right. There was separate ulceration in the centre of the dorsum (Fig. 2). He had no cough or sputum. There were no other abnormal clinical findings. His peripheral blood picture, electrolytes, serum proteins, and liver function tests were all normal. The erythrocyte sedimentation rate was 28 $\mathrm{mm}$ in the first hour (Westergren). The chest radiograph showed a dense opacity with elongated transradiancy filling the apex of the right hemithorax, suggestive of an apical empyema. The remainder of the lung fields was clear (Fig. 3).
FIG. 3. Case 1. 1965. Postero-anterior chest radiograph showing opacity at apex of right hemithorax with apparent cavitation ? apical empyema.

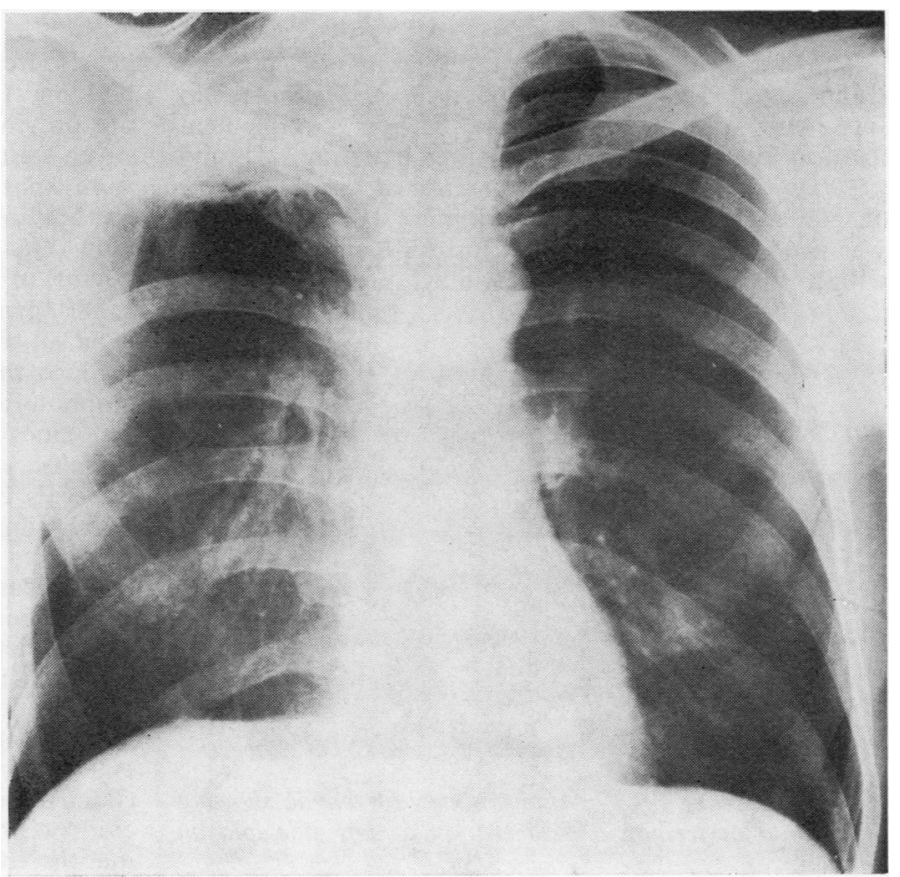




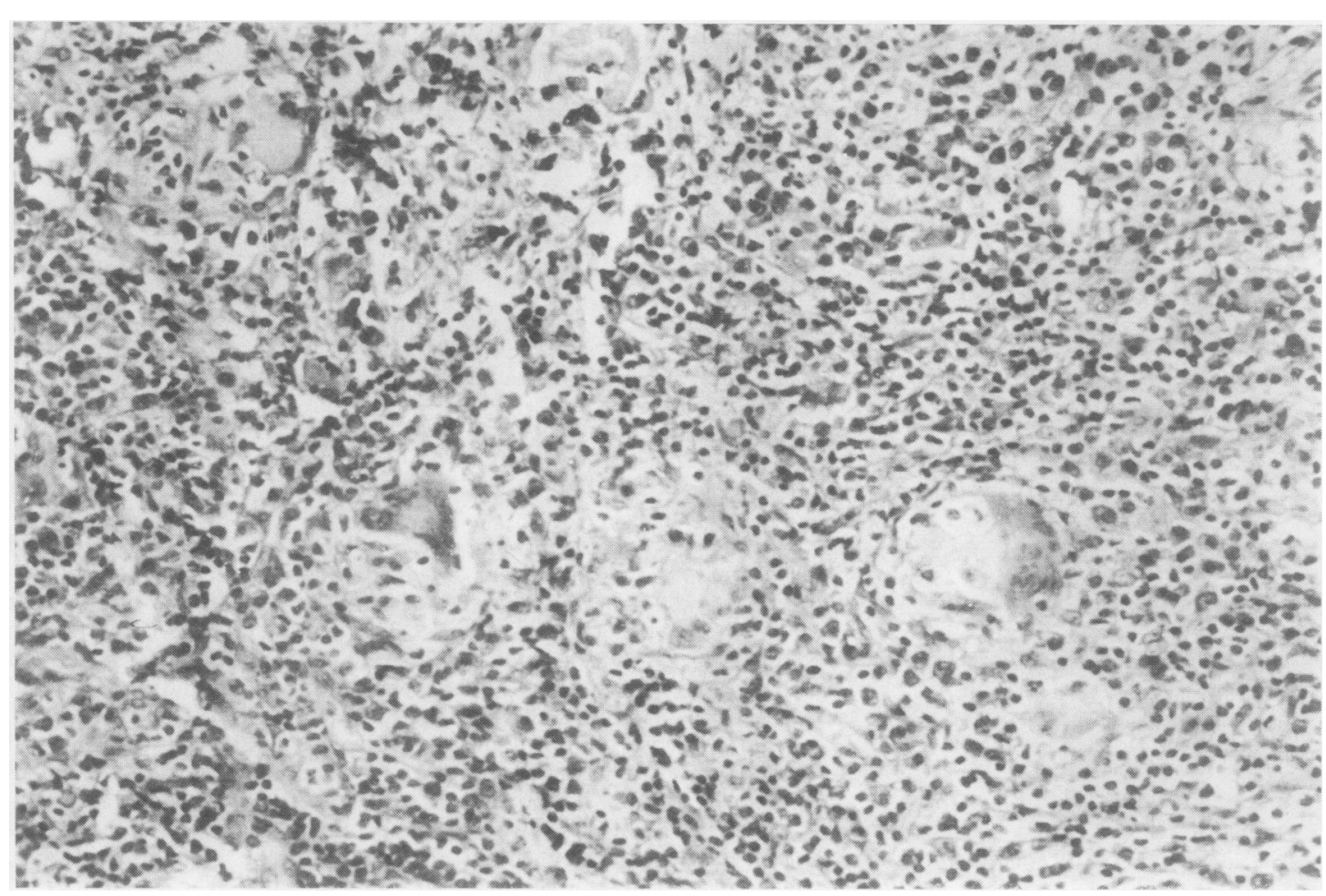

FIG. 4. Case 1. Tongue biopsy showing giant-cell histiocytic granulomata. H. \& E. $\times 130$.

The tuberculin skin sensitivity test was positive (Mantoux 1/1,000: $2 \mathrm{~cm}$ induration). Histoplasmin skin test was negative. Histoplasmin complement fixation test was positive with titres between 1/50 and $1 / 100$. A repeat tongue biopsy showed large numbers of giant-cell histiocytic granulomata (Fig. 4). There was no caseation. Definite histoplasma were seen within the giant cells. In 'Gridley' preparations the

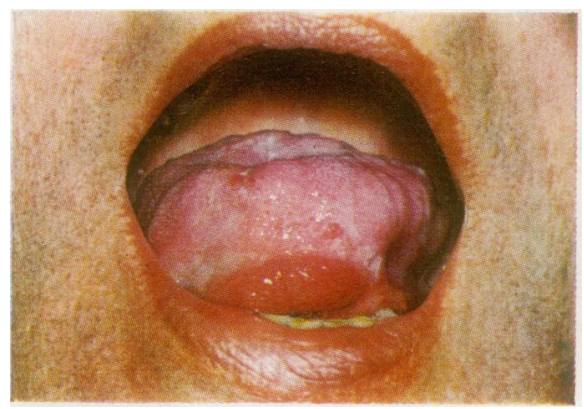

FIG. 5. Case 1. 1968. Anterior view of tongue showing granuloma at frenum and ulceration at left side and on dorsum. yeasts were also seen outside the giant cells and budding forms were recognized. Re-examination of the previous biopsy using Grocott-Gomori hexamine $\underset{\times}{\otimes}$ silver stain demonstrated histoplasma. The organisms $\dot{0}$ were sparse but the apparent budding forms were 3 . unusually conspicuous. Culture of the second biopsy grew Histoplasma capsulatum. The fungus was resistant to $500 \mu \mathrm{g} / \mathrm{ml}$ amphotericin but sensitive to

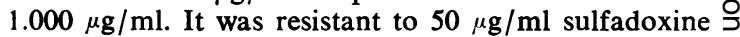
(Fanasil, Ro $4-4393$ ) but sensitive to $100 \mu \mathrm{g} / \mathrm{ml}$.

Since the patient refused intravenous therapy with amphotericin, he was treated successively with sul- $N$ fadoxine for 11 months, oral amphotericin for $9 \%$ months, and sulphadimidine for 7 months with $N$ intervals between each course. There was slight tem- N porary improvement while taking sulfadoxine for the $\omega$ first three months but afterwards slow progression of the disease in the tongue continued. The whole 0 tongue became scarred and deformed and protrusion $\overparen{D}$ was difficult (Fig. 5). Eating was painful and dis-? tressing. The lung lesion had shown no change for 0 at least five years. On the suggestion of one of us (I.G.M.) treatment was started with trimethoprim, $\mathbb{D}$ $160 \mathrm{mg}$, combined with sulphamethoxazole, $800 \mathrm{mg} \frac{}{\mathbb{\Phi}}$ (Bactrim or Septrin) twice daily. Some healing was $\varrho$ evident at the end of the first month and after 10 months this was almost complete except for a slight 8 
superficial ooze on the left and a small decreasing button of granulation tissue under the frenum. The tongue remains scarred and deformed but is more mobile and free from pain (slight relapse in November 1971).

CASE 2 G.C., a male railway employee, was born of British parentage in India in 1905. He had lived in Calcutta and travelled extensively in Eastern India. He recalled no illness of significance. In 1947 he came to stay in England for good and obtained work in a car factory.

In April 1957 he was admitted to hospital with a myocardial infarction complicated by pericarditis and transient disturbances of rhythm. He recovered and during the following five years suffered from angina of effort. He was readmitted in December 1964 with an increase in chest pain. He mentioned that for six months he had slowly lost weight and had poor appetite and ill-defined epigastric and back pains. $\mathrm{He}$ had noticed increasing fatigue and more recently had been vomiting. He looked ill and wasted. There were small areas of vitiligo on the skin of the forearms, but pigmentation was not prominent and was absent from the buccal mucosa. An electrocardiogram showed left bundle-branch block. Serum aspartate aminotransferase was 116 i.u. Plasma electrolytes were within the normal range. His condition deteriorated and after two weeks, during which the serum sodium fell to $126 \mathrm{mEq} / 1$, he collapsed and died.

At necropsy the oral cavity, the larynx, trachea, and main bronchi were normal. The lungs were oedematous and there were a few calcified foci in the left upper lobe. The heart was small-230 g. There was extensive scarring which involved the ventricular septum and the anterior wall of the left ventricle, but there was no gross evidence of recent infarction. The liver and spleen appeared congested.

The adrenal glands were symmetrically enlarged, each measuring $7 \times 5 \mathrm{~cm}$ and weighing $65 \mathrm{~g}$. Their external surfaces were smooth and lobulated and the cut surfaces showed complete destruction of both glands by soft, white caseous material. From the macroscopic appearances tuberculosis was strongly suspected but no acid-fast bacilli were found in the smears from the adrenal glands nor in the histological sections; and culture for Myco. tuberculosis proved negative. Routine sections showed replacement of the glands by caseous debris; this was walled off by fibrous tissue containing some non-specific inflammatory cells. A few multinucleated giant cells were present but there was no typical 'tuberculide' reaction. Routine sections also showed numerous tiny ovoid bodies, about $3 \mu$ in diameter. These were unstained but their somewhat refractile nature made them stand out against the necrotic background. They also proved to be doubly refractile and stained positively with PAS and methenamine silver. A diagnosis of adrenal histoplasmosis was made. Hyphate forms grew in culture and the identity of $H$. capsulatum was confirmed by Professor W. St. C. Symmers. There was no evidence of histoplasmosis elsewhere in the body.

CASE 3 A.S. was a regular soldier born in 1905. He had served abroad in Europe, Nigeria, Iraq, the Sudan, and India. He developed rheumatoid arthritis in 1948 and returned to England for the last time in 1949. He continued work as a commerical traveller for 10 years until his arthritis forced his retirement in 1959.

He was treated at first with a variety of drugs including phenylbutazone. Corticosteroids were started in 1953; for a few months he had ACTH and then cortisone, $75 \mathrm{mg}$ daily, which was continued up to 1967.

In July 1967, still suffering from progressive rheumatoid disease, he was admitted to hospital complaining especially of lack of energy, lethargy, and undue loss of weight during the previous six months. He had developed a cough with mucoid sputum and was now short of breath on moderate activity. He had had rigors with fever and sweating. On admission the temperature was $102^{\circ} \mathrm{F}$. There were signs of rheumatoid deformity in both hands and of effusion into the right knee joint. There were subcutaneous nodules over both elbows. His spleen was enlarged and the liver edge was palpable and firm. B.P. was $120 / 80$ $\mathrm{mmHg}$.

INVESTIGATIONS Haemoglobin $9.9 \mathrm{~g} / 100 \mathrm{ml}$, serum iron $20 \mu \mathrm{g} / 100 \mathrm{ml}$, leucocytes $5,000 / \mathrm{mm}^{3}$, normal differential count. Erythrocyte sedimentation rate 53 $\mathrm{mm}$ in one hour (Westergren). Plasma electrolytes normal. Plasma albumen $2 \cdot 1 \mathrm{~g} / 100 \mathrm{ml}$, globulin 4.6 g/100 ml. Rose-Waaler D.A.T. positive 64 units. Sputum culture was negative for Myco. tuberculosis but showed a heavy growth of monilia. In the chest radiograph there was shadowing at the right apex. On the left there were linear densities stretching up and out from the hilar region to the apex. Tomography confirmed these findings and revealed on the right a thin-walled cavity at the apex, $2 \times 1 \mathrm{~cm}$. On the left there were several small transradiancies in a linear 'fibrotic' network in the upper lobe (Fig. 6). The appearances were suggestive of tuberculous disease with probable activity at the right apex.

Treatment was started with streptomycin, sodium PAS, and isoniazid. An attempt to wean him from corticosteroids failed and they were continued as prednisone, $5 \mathrm{mg}$ twice daily. Progress was unsatisfactory with continuing fever and loss of weight. The liver increased in size. Serum bilirubin rose to $1.6 \mathrm{mg} /$ $100 \mathrm{ml}$, serum aspartate aminotransferase to 46 units/ $\mathrm{ml}$, and alkaline phosphatase to 30 units $/ \mathrm{ml}$. Liver biopsy showed granulomatous lesions scattered throughout the parenchyma; many of these lesions were surrounded by a mantle of polymorphs, which were also present in the portal tracts. Haemoglobin was $10.2 \mathrm{~g} / 100 \mathrm{ml}$ and leucocytes $2,400 / \mathrm{cmm}^{3}$, with $88 \%$ neutrophils and $12 \%$ lymphocytes. Platelets were reduced to $49,000 / \mathrm{mm}^{3}$. A marrow aspiration sample was essentially normal with slight plasma-cell infiltration. 


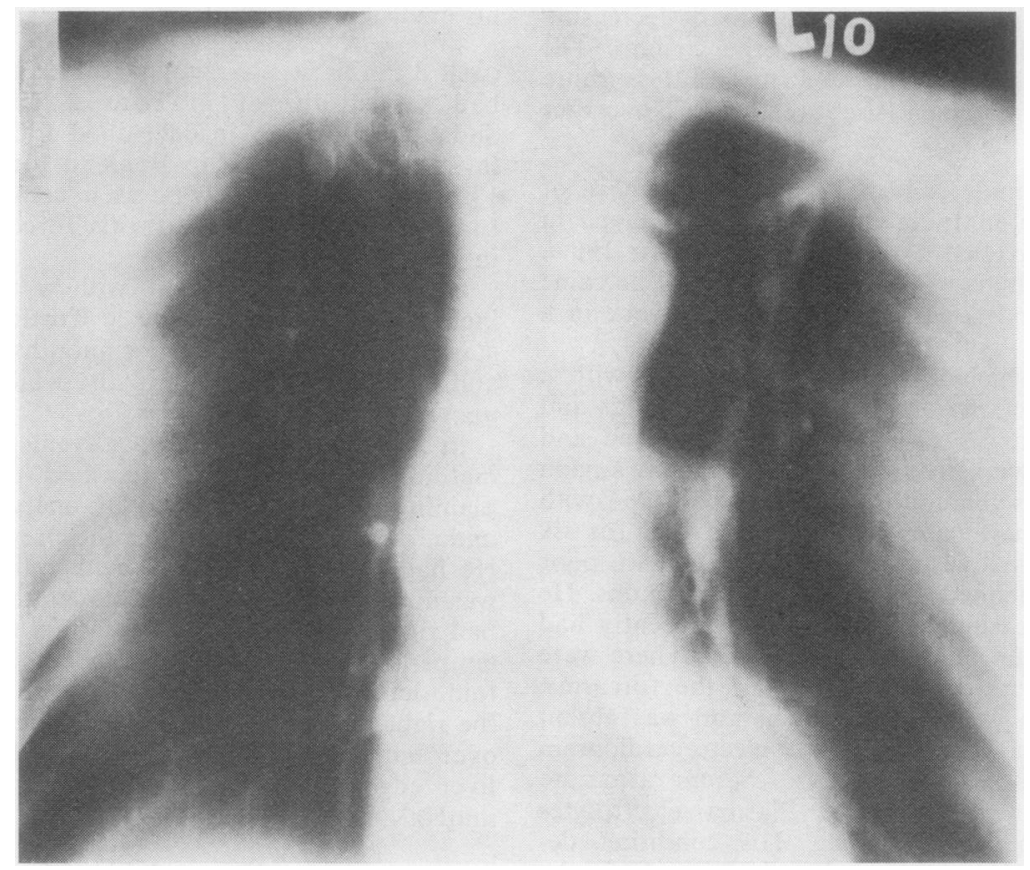

FIG. 6. Case 3. 1967. Tomogram section of both upper lungs, $10 \mathrm{~cm}$ posterior cut, showing a thin-walled cavity, $2 \times 1 \mathrm{~cm}$, at right apex and linear network in left upper lobe.

His condition deteriorated further. He developed a left-sided spontaneous pneumothorax and died a few days later in December 1967.

At necropsy the body was emaciated. The larynx and trachea were normal but the bronchi contained frothy sputum. The right lung showed an apical cavity and the surfaces of the lungs were studded with giant emphysematous bullae. The heart was of normal size but the left ventricle was hypertrophied and the right coronary artery partly occluded by atheroma. The abdominal aorta was atheromatous with a very thickened but soft wall. The liver weighed $3.025 \mathrm{~g}$ but, apart from some pallor, appeared normal. The spleen weighed $122 \mathrm{~g}$ and showed one white area but no other significant abnormality. The right kidney was of normal size and the left was enlarged; in both there were several caseous areas. Both adrenals showed multiple areas of caseation.

Histologically, in both adrenals and kidneys there were foci of necrosis containing numerous ovoid refractile bodies about $3 \mu$ in diameter. There were also numerous organisms in the surrounding macrophages. The organisms could be demonstrated by Grocott's method, and their capsules stained by periodic acid Schiff technique (Fig. 7). Morphologically the appearances were compatible with $H$. capsulatum. The organisms could also be demonstrated in the atheromatous wall of the aorta (Fig. 8). Scanty organisms were present in the small granulomata in the liver. The lungs showed areas of necrosis surrounded by fibrous tissue. No organisms could be demonstrated, and the appearances were more suggestive of a rheumatoid aetiology than of a previous histoplasma infection.

\section{DISCUSSION}

The first patient in Britain to be recognized with응 active histoplasmosis was a soldier who had served abroad in India and the Sudan as well as in Europe (Derry, Card, and Wilson, 1942). The N occurrence of infection in persons who have never left these islands is extremely rare. There are two possible instances. Limerick (1951) briefly reported $\omega$ finding the fungus in pus from an appendicular abscess. The fungus was not cultured ande Symmers (1956a) has questioned the reliability $\Phi$ of the diagnosis. Symmers himself cultured? histoplasma from a lymph node removed for ${ }^{-}$ biopsy from a man of 56 years. The patient? had always lived in England or Ireland. In 1936 he cut his forehead in Ireland. He developed scarō sarcoid in 1950 and in the following year showedo evidence of disseminated sarcoidosis. This resolved 


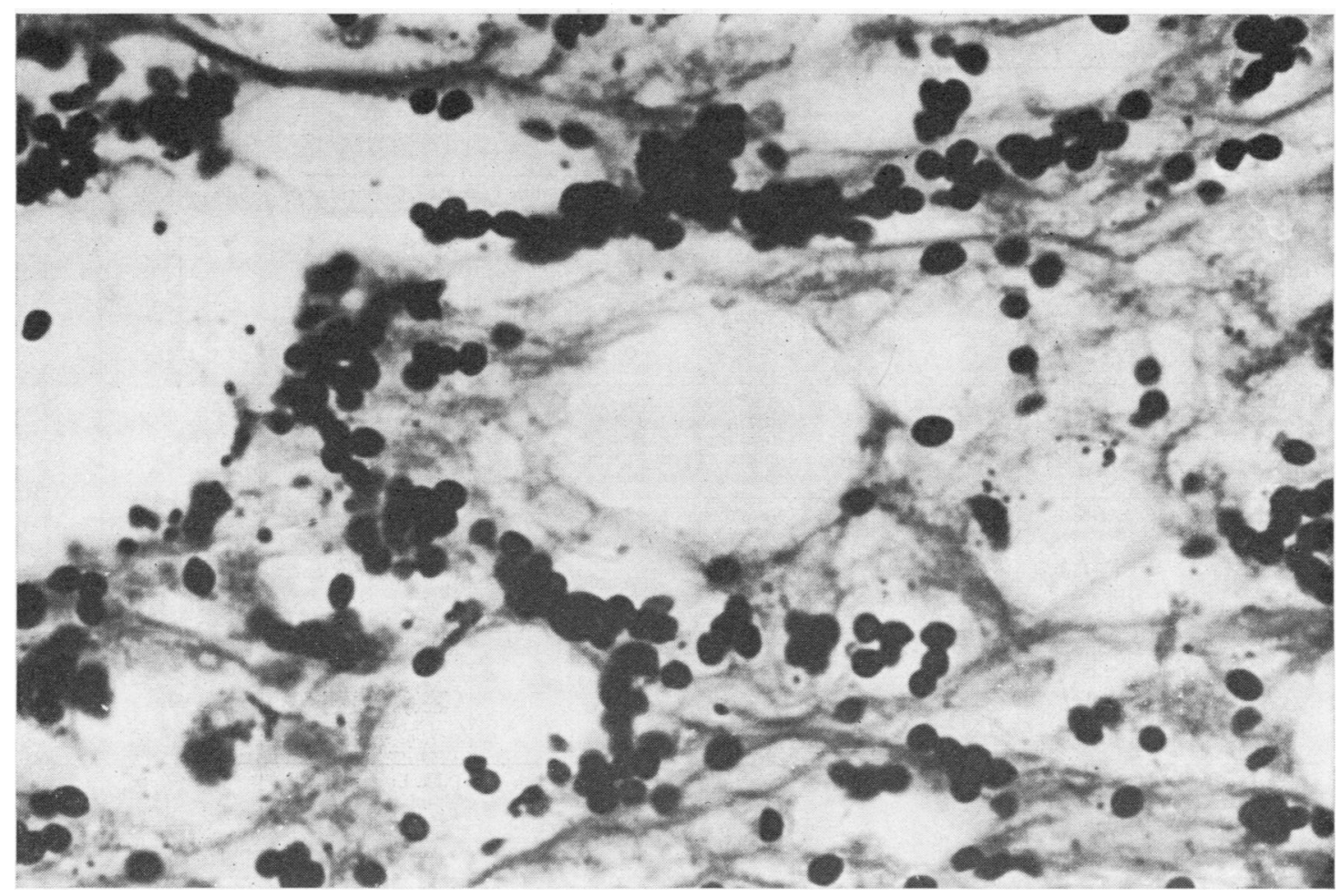

FIG. 7. Case 3. Section from adrenal gland showing numerous histoplasma organisms in matrix. Grocott's method, $\times 550$

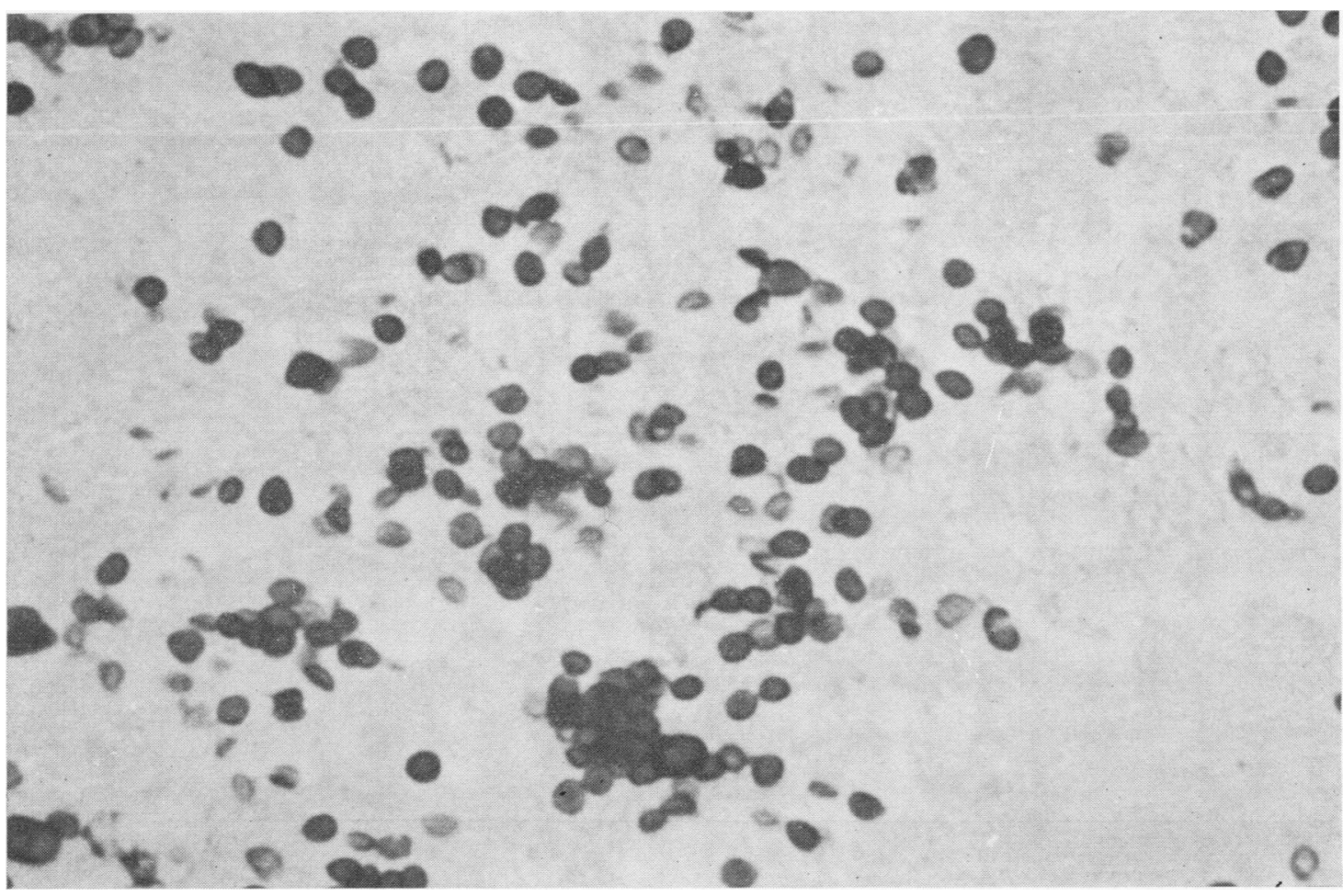

FIG. 8. Case 3. Histoplasma capsulatum in wall of aorta. Grocott's method, $\times 550$. 
T A B LE I

SUMMARY OF PATIENTS WITH ACTIVE DISSEMINATED HISTOPLASMOSIS DIAGNOSED IN GREAT BRITAIN

\begin{tabular}{|c|c|c|c|c|c|c|c|c|c|c|c|}
\hline $\begin{array}{l}\text { Refer- } \\
\text { ence }\end{array}$ & Sex & Age & Work & Countries & $\left|\begin{array}{l}\text { Home } \\
\text { Period }^{2}\end{array}\right|$ & Clinical Features & $\underset{\text { tion }^{3}}{\text { Dura- }}$ & $\begin{array}{c}\text { Biopsy } \\
\text { Histoplasma Present }\end{array}$ & Culture & $\mid \begin{array}{c}\text { Histo- } \\
\text { plasmin } \\
\text { Skin } \\
\text { Test }\end{array}$ & $\begin{array}{l}\text { Comple- } \\
\text { ment } \\
\text { Fixation } \\
\text { Test }\end{array}$ \\
\hline $\begin{array}{l}\text { Derry } \\
\text { et al. } \\
(1942)\end{array}$ & $\mathbf{M}$ & 30 & $\begin{array}{l}\begin{array}{l}\text { General } \\
\text { labourer }\end{array} \\
\text { Armed } \\
\text { services }\end{array}$ & $\begin{array}{l}\text { India, } \\
\text { Sudan, } \\
\text { France }\end{array}$ & $\begin{array}{l}\text { India } \\
\text { 3-4 yr, } \\
\text { Sudan } \\
2-3 \text { yr, } \\
\text { France } \\
4 \text { mth }\end{array}$ & $\begin{array}{l}\text { Cough, pleurisy, fever, } \\
\text { loss of weight. Cervical } \\
\text { lymph nodes }+ \text {, and } \\
\text { abscess, liver }+ \text {, } \\
\text { spleen }+\end{array}$ & $\begin{array}{l}9 \mathrm{mth} \\
\text { Died }\end{array}$ & $\begin{array}{l}\text { A.M. Cervical and } \\
\text { inguinal nodes } \\
\text { P.M. Rectroperiton- } \\
\text { eal mass (adrenals } \\
\text { not identified); } \\
\text { tonsils, cervical } \\
\text { nodes, spleen, } \\
\text { peritoneum, small } \\
\text { and large bowel }\end{array}$ & $+\mathrm{ve}$ & 0 & 0 \\
\hline $\begin{array}{l}\text { Locket } \\
\text { et al. } \\
\text { (1953) }\end{array}$ & $\mathbf{M}$ & 32 & $\begin{array}{l}\text { Armed } \\
\text { services }\end{array}$ & $\begin{array}{l}\text { Near East, } \\
\text { North Africa, } \\
\text { India }\end{array}$ & $6-7 \mathrm{yr}$ & $\begin{array}{l}\text { Abdominal pain, fever, } \\
\text { loss of weight, mouth } \\
\text { ulceration, anaemia, } \\
\text { spleen }+, \text { liver }+ \text {, lung } \\
\text { shadows, skin ulcers }\end{array}$ & $\begin{array}{l}12-15 \\
\text { mth } \\
\text { Died }\end{array}$ & $\begin{array}{l}\text { P.M. Liver, spleen, } \\
\text { lymph nodes, lung, } \\
\text { bone marrow, } \\
\text { thyroid, adrenals, } \\
\text { and skin }\end{array}$ & $+\mathrm{ve}$ & $-\mathrm{ve}$ & 0 \\
\hline $\begin{array}{l}\text { Poles and } \\
\text { Lavertine } \\
\text { (1954) }\end{array}$ & $\mathbf{M}$ & 45 & $\begin{array}{l}\text { Armed } \\
\text { services } \\
\text { Post office } \\
\text { clerk }\end{array}$ & $\begin{array}{l}\text { France, } \\
\text { Nigeria, } \\
\text { Burma }\end{array}$ & $6 \mathrm{yr}$ & $\begin{array}{l}\text { Sore throat, hoarse } \\
\text { voice, miliary shadows } \\
\text { chest radiograph, } \\
\text { fever, loss of weight, } \\
\text { cough, dyspnoea, } \\
\text { diarrhoea, spleen + }\end{array}$ & $\begin{array}{l}9 \mathrm{mth} \\
\text { Died }\end{array}$ & $\begin{array}{l}\text { A.M. Larynx } \\
\text { P.M. Larynx, } \\
\text { trachea, lungs, and } \\
\text { adrenals }\end{array}$ & - ve & -ve & 0 \\
\hline $\begin{array}{l}\text { Earle } \\
\text { et al. } \\
\text { (1960) }\end{array}$ & $\mathbf{M}$ & 62 & Forestry & $\begin{array}{l}\text { India, } \\
\text { Pakistan }\end{array}$ & $\begin{array}{l}\text { Few } \\
\text { mth }\end{array}$ & $\begin{array}{l}\text { Loss of weight, } \\
\text { anorexia, tiredness, } \\
\text { mental change, tongue } \\
\text { ulcer, anal ulcer, fever, } \\
\text { anaemia, spleen }+ \text {, } \\
\text { liver }+, \text { haematuria }\end{array}$ & $\begin{array}{l}10 \mathrm{mth} \\
\text { Died }\end{array}$ & $\begin{array}{l}\text { A.M. Tongue, anus } \\
\text { P.M. Adrenals, } \\
\text { kidneys }\end{array}$ & 0 & 0 & $\begin{array}{l}\text { Anti- } \\
\text { comple- } \\
\text { mentary }\end{array}$ \\
\hline $\begin{array}{l}\text { Miller } \\
\text { et al. } \\
\text { (1961) }\end{array}$ & $\mathbf{M}$ & 61 & $\begin{array}{l}\text { Yardman } \\
\text { cotton } \\
\text { mill }\end{array}$ & Dardanelles & $\begin{array}{l}40-41 \\
\text { yr }\end{array}$ & $\begin{array}{l}\text { Cough, sputum, } \\
\text { breathlessness, loss of } \\
\text { weight, extensive } \\
\text { bilateral shadowing } \\
\text { chest radiograph }\end{array}$ & $\begin{array}{l}6 \mathrm{mth} \\
\text { Died }\end{array}$ & $\begin{array}{l}\text { P.M. Lungs, hilar } \\
\text { lymph nodes, } \\
\text { adrenals, prostate }\end{array}$ & 0 & $\mathbf{0}$ & 0 \\
\hline $\begin{array}{l}\text { Murray } \\
\text { and } \\
\text { Sladden } \\
\text { (1965) }\end{array}$ & $\mathbf{F}$ & 66 & Housewife & India & $10 \mathrm{yr}$ & $\begin{array}{l}\text { Reticulosarcoma } \\
\text { treated with cortico- } \\
\text { steroids; fever, } \\
\text { anaemia, purpura, } \\
\text { oedema, spleen }++ \text {, } \\
\text { drowsy, albuminuria }\end{array}$ & $\begin{array}{l}\text { under } \\
? 12 \mathrm{mth} \\
\text { Died }\end{array}$ & $\begin{array}{l}\text { A.M. Bone marrow } \\
\text { P.M. Heart, lungs, } \\
\text { liver, spleen, and } \\
\text { other organs }\end{array}$ & $+\mathrm{ve}$ & -ve & 0 \\
\hline $\begin{array}{l}\text { Partridge } \\
\text { and } \\
\text { Tanser } \\
\text { (1966) }\end{array}$ & $\mathbf{F}$ & 42 & Housewife & $\begin{array}{l}\text { Malaya, } \\
\text { India, } \\
\text { Ceylon, } \\
\text { U.S.A., } \\
\text { Hawaii, } \\
\text { Japan, } \\
\text { Hong Kong }\end{array}$ & ? $1 \mathrm{yr}$ & $\begin{array}{l}\text { Dental abscess, fever, } \\
\text { lethargy, dyspnoea, } \\
\text { loss of weight, } \\
\text { dysphagia, liver }+ \text {, } \\
\text { spleen }+, \text { laryngeal } \\
\text { ulcer, adrenal failure }\end{array}$ & $\begin{array}{l}3 \text { yr } \\
\text { plus } \\
\text { Alive }\end{array}$ & $\begin{array}{l}\text { Larynx, subphrenic } \\
\text { abscess }\end{array}$ & $+\mathrm{ve}$ & $-\mathrm{ve}$ & $\begin{array}{r}+\mathrm{ve} \\
1 / 512\end{array}$ \\
\hline $\begin{array}{l}\text { Aldridge } \\
\text { et al. } \\
\text { (1970) }\end{array}$ & $\mathbf{M}$ & 63 & $?$ & Burma & $? 17 \mathrm{yr}$ & $\begin{array}{l}\text { Loose bowels, loss of } \\
\text { weight, lassitude, } \\
\text { liver }+ \text {, spleen +, } \\
\text { anaemia, ankle } \\
\text { oedema; laparotomy; } \\
\text { colon perforation; } \\
\text { large retroperitoneal } \\
\text { mass; secondary } \\
\text { haemorrhage, gastric } \\
\text { artery }\end{array}$ & $\begin{array}{l}5 \mathrm{yr} \\
\text { Died }\end{array}$ & $\begin{array}{l}\text { A.M. Colon, spleen, } \\
\text { granulation tissue } \\
\text { P.M. Adrenals, } \\
\text { gastric ulcer abscess } \\
\text { wall, also in small } \\
\text { vessels of pancreas, } \\
\text { liver, lungs, and } \\
\text { kidneys }\end{array}$ & + ve & 0 & $\begin{array}{l}\text { Precipi- } \\
\text { tation } \\
\text {-ve } \\
\text { Yeast- } \\
\text { phase } \\
\text { comple- } \\
\text { ment } \\
\text { fixation } \\
\text { + ve } 1 / 10\end{array}$ \\
\hline $\begin{array}{l}\text { Present } \\
\text { series (1) }\end{array}$ & $\mathbf{M}$ & 40 & $\begin{array}{l}\text { Armed } \\
\text { services }\end{array}$ & $\begin{array}{l}\text { Burma, } \\
\text { Malaya, } \\
\text { Java, } \\
\text { Europe }\end{array}$ & $6 \mathrm{yr}$ & $\begin{array}{l}\text { ? pulmonary tubercu- } \\
\text { losis; tongue ulcer, } \\
\text { loss of weight, } \\
\text { Addison's disease, } \\
\text { spleen + }\end{array}$ & $\begin{array}{l}9 \text { yr } \\
\text { Alive }\end{array}$ & Tongue & + ve & -ve & $\begin{array}{l}+\mathrm{ve} \\
1 / 160\end{array}$ \\
\hline (2) & $\mathbf{M}$ & 58 & $\begin{array}{l}\text { Railway } \\
\text { employee }\end{array}$ & India & $16 \mathrm{yr}$ & $\begin{array}{l}\text { Loss of weight, } \\
\text { anorexia, weakness, } \\
\text { vomiting, epigastric } \\
\text { pain, myocardial } \\
\text { infarction }\end{array}$ & $\begin{array}{l}2 \text { wk } \\
\text { Died }\end{array}$ & P.M. Adrenal glands & $+\mathrm{ve}$ & 0 & 0 \\
\hline (3) & $\mathbf{M}$ & 63 & $\begin{array}{l}\text { Armed } \\
\text { services }\end{array}$ & $\begin{array}{l}\text { India, } \\
\text { Iraq } \\
\text { Sudan, } \\
\text { Nigeria, } \\
\text { Europe }\end{array}$ & $18 \mathrm{yr}$ & $\begin{array}{l}\text { Rheumatoid disease } \\
\text { treated with cortisone; } \\
\text { lethargy, recurrent } \\
\text { fever, bilateral upper } \\
\text { lobe shadowing chest } \\
\text { radiograph, anaemia. } \\
\text { spleen }+ \text {, liver - }\end{array}$ & $\begin{array}{l}12 \mathrm{mth} \\
\text { Died }\end{array}$ & $\begin{array}{l}\text { P.M. Adrenal glands, } \\
\text { kidney, liver, aorta }\end{array}$ & 0 & 0 & 0 \\
\hline \multicolumn{12}{|c|}{$\begin{array}{ll}\text { Age at onset of symptoms. } & 0=\text { no information. } \\
2 \text { Period between return from abroad and onset of symptoms. } & \text { A.M. }=\text { antemortem; P.M.=postmortem. } \\
3 \text { Duration of illness from first symptom. } & \text { Oे }\end{array}$} \\
\hline
\end{tabular}


T A B L E I I

SUMMARY OF PATIENTS WITH LOCALIZED ACTIVE HISTOPLASMOSIS DIAGNOSED IN GREAT BRITAIN

\begin{tabular}{|c|c|c|c|c|c|c|c|c|c|}
\hline Reference & Sex & Age & Work & Countries & Clinical Features & Biopsy & Culture & $\begin{array}{l}\text { Histo- } \\
\text { plasmin } \\
\text { Skin } \\
\text { Test }\end{array}$ & $\begin{array}{l}\text { Comple- } \\
\text { ment } \\
\text { Fixation } \\
\text { Test }\end{array}$ \\
\hline $\begin{array}{l}\text { Duncan } \\
\text { (1945; } \\
\text { 1947) }\end{array}$ & $\mathbf{M}$ & 63 & $?$ & West Africa & Papulocircinate lesions on skin; biopsy & +ve & + ve & $\mathbf{0}$ & $\mathbf{0}$ \\
\hline $\begin{array}{l}\text { Limerick } \\
\text { (1951) }\end{array}$ & $\mathbf{M}$ & 35 & $?$ & Never & Inguinal abscess following appendicectomy & $\begin{array}{l}\text { Pus } \\
+ \text { ve }\end{array}$ & $-\mathrm{ve}$ & 0 & $\mathbf{0}$ \\
\hline $\begin{array}{l}\text { Hutchison } \\
\text { (1952) }\end{array}$ & $\mathbf{M}$ & 72 & $\begin{array}{l}\text { Mining } \\
\text { engineer }\end{array}$ & $\begin{array}{l}\text { India, } \\
\text { Malaya }\end{array}$ & $\begin{array}{l}\text { After } 14 \text { yr in Great Britain developed husky } \\
\text { voice; ulceration of right vocal cord; biopsy: } \\
\text { healed in } 3 \text { yr }\end{array}$ & +ve & $-\mathbf{v e}$ & $\mathbf{0}$ & $\mathbf{0}$ \\
\hline $\begin{array}{l}\text { Symmers } \\
\text { (1956a) }\end{array}$ & $\mathbf{M}$ & 56 & $?$ & Never & $\begin{array}{l}1936 \text { cut forehead; } 1950 \text { scar sarcoid; } 1951 \text { lung } \\
\text { infiltration, generalized peripheral lymph node } \\
\text { enlargement; biopsy-sarcoidosis, resolution } \\
\text { in } 12 \text { mth; 1955 recurrent supraclavicular } \\
\text { lymph node enlargement; biopsy }\end{array}$ & +ve & +ve & +ve & $\mathbf{0}$ \\
\hline $\begin{array}{l}\text { Symmers } \\
\text { (1956b) }\end{array}$ & $\mathbf{M}$ & 28 & Student & Nigeria & $\begin{array}{l}1951 \text { pustule on cheek, ? insect bite; healed with } \\
\text { nodule, } 1953 \text { nodule ulcerated; biopsy }\end{array}$ & +ve & +ve & - ve & 0 \\
\hline $\begin{array}{l}\text { Symmers } \\
\text { (1956b) }\end{array}$ & $\mathbf{F}$ & 23 & Student & Nigeria & $\begin{array}{l}\text { Annular skin lesion over lower sternum slowly } \\
\text { enlarging over } 2 \text { yr; biopsy }\end{array}$ & +ve & + ve & +ve & $\mathbf{0}$ \\
\hline
\end{tabular}

spontaneously during the next 12 months. In 1955 two small cervical nodes re-enlarged and it was from one of these that the fungus was cultured.

Another possible instance of infection occurring in these islands was in a man aged 61 years. He was a yardman in a cotton mill. At his work he had close dusty contact with bales of cotton from America and Nigeria. Forty years previously he had spent a year in the Dardanelles but otherwise had always lived in England. He died from extensive disseminated disease thought to be tuberculous until the fungus was seen in necropsy specimens (Miller, Ramsden, and Geake, 1961).

If the fungus is present in these islands, why is the initial infection so rare? Two small skin test surveys have shown no positive reactors (McCracken, 1948 ; Evans, 1949). Knight, considering this problem, has pointed out that the mean summer temperature compares favourably with areas in Canada from which histoplasma infection has been reported and also with Bergen in Norway where skin test surveys have yielded $4.7 \%$ of positive reactors (Knight, 1968). Knight suggests that a further survey in Great Britain, especially in those areas with an adequate rainfall and high acid soil, might be rewarding.

Altogether, there have been eight reports of active disseminated histoplasmosis first diagnosed in Great Britain (Table I). To these we now add three further examples. There have also been reports of patients with apparently localized histoplasmosis (Table II). In three of these there was a skin lesion, in one the larynx was involved, in one a cervical lymph node was infected, and in a sixth an appendix abscess, as cited above. There have been several reports of healed pulmonary disease presenting with multiple calcified foci and the diagnosis presumed from the history of travel abroad and a positive skin test reaction (Arblaster, 1950 ; Crofton, 1950; Sakula, 1953 ; Leigh and Thomas, 1955).

\section{THE CLINICAL PICTURE}

The natural history of the disease is outlined in Table III. Infection most commonly occurs following the inhalation of soil dust laden with fungal spores, the primary lesion developing in the lungs. There may be a single focus or several, or even multiple bilateral foci. When the latter heal with calcification they present a distinctive radiographic picture (Arblaster, 1950 ; Crofton, 1950). Primary

\section{T A B L E I I I}

\footnotetext{
Primary lesion

1. Lungs - single, several or multiple bilateral foci with related 2. Skin (? oropharynx)

Post-primary lesions

1. Lungs

(a) Acute bronchopneumonia

(b) Chronic infiltration, fibrosis, cavitation, and round foci Very similar to tuberculosis. Fungus rarely found in sputum.

2. Disseminated disease

(a) Acute, see text

(b) Chronic, see text

3. Other thoracic presentations

(a) Pleurisy with effusion

(b) Mediastinitis; superior vena-caval obstruction

(c) Pericarditis, acute or constrictive
} 
lesions of the skin are less common. Three patients presenting with solitary skin granulomas have been recognized in Great Britain (Duncan, 1947; Symmers, 1956a, b) (Table II). In all three cases infection started in West Africa. Local skin granulomata may be a feature of the African disease with Histoplasma duboisii infection (Lucas, 1968). While disseminated skin lesions are common to both types, primary skin foci in American histoplasmosis-H. capsulatum infection-are said to be extremely uncommon (Furcolow, 1960). Primary gastrointestinal infection, though experimentally demonstrated, has not been proven in man. Children may present with gut infection, often with related lymphadenitis, but this follows primary lung disease or is part of disseminated histoplasmosis (Soper, Silber, and Holcomb, 1970).

The primary lung focus usually heals without producing symptoms. The diagnosis is reasonably inferred from a positive skin reaction to histoplasmin and a negative response to tuberculin, and possibly a calcified scar in the chest radiograph. In a few persons the lung disease develops either as an acute bronchopneumonia or more indolently with infiltration, cavitation, and fibrosis indistinguishable in the radiograph from pulmonary tuberculosis. The fungus is rarely found in the sputum and the diagnosis may again depend on differential skin sensitivities. The patient whose illness was recorded by Miller et al. (1961) presented with acute bronchopneumonia and died with disseminated disease. In our first case, histoplasmosis was not considered at the time of lobar resection; also while cultures were negative for Myco. tuberculosis, acid-fast bacilli were seen in the smears from the right upper lobe. In our case 3 no histoplasma were seen in the lungs at necropsy and no cultures were taken. It is possible that in both these patients there was a coincident tuberculous infection though in the third case the histological appearances suggested rheumatoid lung disease. Pleurisy with effusion is an infrequent development (Schub, Spivey, and Baird, 1966). In some persons histoplasma infection presents as a 'round' pulmonary focus simulating a tuberculoma or a nodular growth.

Dissemination of the fungus to other parts of the body may or may not be accompanied by recognizable lung lesions. It is this form of disease which is the outstanding presentation of active histoplasmosis in Great Britain. The dissemination may be acute and fulminating, mimicking acute haematogenous tuberculosis with fever, loss of weight, enlarged liver, and palpable spleen. There may be generalized lymphadenopathy, meningitis, and miliary dissemination in the lungs, death $\stackrel{\overrightarrow{\bar{c}}}{\frac{\overrightarrow{5}}{0}}$ following in a few months from the onset of infection (Table I).

Chronic disseminated histoplasmosis is much $\frac{\bar{\omega}}{\bar{\sigma}}$ more insidious and prolonged in its invasion (case $\varrho$ 1). It may remain hidden and unrecognized untilœ the sudden development of terminal adrenal failure $\vec{O}$ (cases 2 and 3). Many years of apparent good health may follow infection abroad before death $\vec{\omega}$ in this country (Table I).

The disease may affect many parts of the body $\vec{x}$ but there are two characteristic lesions which are often in the picture:

1. Granulomatous ulceration in the oro-pharynx, tongue, tonsils, pharynx or larynx: while localized orolaryngeal lesions may rarely occur on $\vec{c}$ their own (the case reported by Hutchison in 1952 in this country is a possible example), they are $\frac{2}{d}$ usually features of generalized disease (case 1). In the diagnosis of these granulomata confusion with $\overrightarrow{0}$ tuberculosis is the main difficulty, but the absence of pulmonary disease with tubercle bacilli in the sputum almost excludes a tuberculous aetiology. Sarcoidosis can affect the nasal mucosa but is unlikely to present with an oral granuloma. Blastomycosis and coccidioidomycosis should be con- $\frac{\mathscr{Q}}{\not}$ sidered in patients coming from endemic areas in $\cong$ the American continents. Darling originally found, $\vec{B}$ while surveying the Panama zone, that histoplas- 3 mosis was confused with leishmaniasis. This can easily be distinguished by appropriate staining. Malignant ulcers with macroscopic mimicry are easily identified histologically (Bennett, 1967).

2. Adrenal gland involvement, with almost total caseous destruction but often little clinical or bio-욱 chemical evidence of such destruction until near: death: the destroyed glands are packed witho parasites.

The selection of the adrenal glands as a favour-옹 able site for the growth of the histoplasma fungus has been recognized for many years (Parsons and Zarafonetis, 1945). Baker (1968) comments that N the organisms grow well in the steroids of the adrenal cortex. Crispell, Parson, Hamlin, and Hollifield (1956) report on four patients in whomw the diagnosis of histoplasmosis and Addison's? disease was established before death. They colse lected 36 other case reports from the literature and comment that antemortem recognition is rela $-?$ tively rare. In the 11 patients found in Great? Britain with disseminated histoplasmosis the adrenal glands were definitely diseased in nine, $\frac{\mathbb{Q}}{\overparen{D}}$ and in the remaining two the glands were auto- $\triangle$ lysed or not identified separately. In three of the nine patients adrenal destruction was not sus -0 
pected during life. In three others adrenal failure was considered but could not be established during life. In the seventh patient the diagnosis was made only 24 hours before death, and only in the remaining two patients was Addison's disease confirmed and treated successfully with survival.

In England tuberculosis is still a frequent cause of Addison's disease. Out of 56 persons between the ages of 25 and 69 years who died from this disease in London during the years 1960-64, 28 died from tuberculosis of the adrenals, 27 had simple atrophy of the glands, and one person had histoplasma infection (Mason, Meade, Lee, and Morris, 1968). Though the latter infection is still rare in this country, histological confusion with tuberculosis is easy unless appropriate search is made for both fungi and bacilli.

In our third patient the abdominal aorta was atheromatous with a thickened but soft wall. Histoplasma organisms were seen in this atheromatous area (Fig. 8). The invasion of the aorta by the fungus is one of the rarer events in disseminated histoplasmosis. Rosenbaum, Schweppe, and Rabin (1964) record the necropsy findings in a patient who died from rupture of a thoracic aortic aneurysm into the left lower lobe. In addition, there was evidence of constrictive pericarditis and a spontaneous pneumopericardium following a bronchopericardial fistula. $H$. capsulatum was demonstrated in the diseased area. Welsh, Coppola, and Capelli (1969) described the case of a 47-yearold man who developed an aneurysm of the femoral artery. He had an enlarged liver and spleen. On biopsy granulomatous lesions were found in liver and muscle. He then developed tongue ulceration, ruptured his abdominal aorta, and showed signs of meningoencephalitis. Biopsy of the aortic wall showed evidence of histoplasmosis. The aorta was repaired with a Dacron graft and following treatment with amphotericin he made an excellent recovery.

Histoplasmosis can also involve the cardiovascular system either as progressive mediastinitis with superior venacaval obstruction (Hewlett, Steer, and Thomas, 1966), or as pericarditis, acute (Kaplan and Sherwood, 1963), or chronic and constrictive (Klieger and Fisher, 1962).

Disseminated histoplasmosis certainly occurs in the American continents, but it would seem probable that those recognized with this disease in Great Britain were infected in India or the Far East (Table I). There is no particular occupation hazard except where individuals such as agricultural workers, demolition labourers, and cave explorers are exposed to the dust from bird droppings. The patient whose illness is recorded by Miller et al. (1961) died from acute disseminated disease. At his work he had been exposed to dusts from cotton bales imported from America and Nigeria, but no proof of infection from this source was obtained.

\section{THE DIAGNOSIS}

The diagnosis in Great Britain should always be considered in anyone showing the features of disseminated disease in whom there is no proof of tuberculous infection and who has lived in endemic areas during the previous 20 years. Confirmation of possible histoplasma infection may readily be obtained by serological methods such as complement fixation or precipitin tests. These are positive in a high percentage of active infections, particularly if the disease is disseminated. Skin sensitivity tests using the antigenic histoplasmin to demonstrate a delayed 'tuberculin' type of sensitivity have been of great value in studying the epidemiology of histoplasmosis. They are of little use and may be misleading in the diagnosis of disseminated disease for in Great Britain and elsewhere they are usually negative with this form of infection. Absolute confirmation can only be obtained during life by culture of biopsy material. On conventional laboratory media at temperatures around $26^{\circ} \mathrm{C}$ the organism grows as a typical filamentous tungus. On certain selective media at $37^{\circ} \mathrm{C}$ the fungus adopts a yeast-like morphology. In vitro the yeasts are oval, approximately $1.5-2.0 \times 3.5$ $\mu$, and usually bud at the poles in actively growing cultures.

Histologically the appearances are not specific. There may be a marked giant-cell reaction without necrosis as in our first case (Fig. 4); or necrosis may be prominent with surrounding macrophages. Invasion of the reticuloendothelial system is characteristic. In routine haematoxylin and eosin preparations, the organisms can be seen as slightly ovoid bodies, $1-5 \mu$ in diameter, with an achromatic doubly refractile capsule. Their presence may be confirmed by more specific stains such as the periodic acid Schiff reaction and by Grocott's modification of Gomori's method. The latter has the advantage of staining dead organisms (Figs 7 and 8) (Symmers, 1960).

\section{TREATMENT}

The treatment of choice is amphotericin given intravenously daily for three to four months. 
Sulphonamides have been used successfully in South America, and Negroni (1964) reported encouragingly on the value of sulfadoxine which was used in the initial treatment of our first patient. There are no available reports on the use of trimethoprim-sulphamethoxazole in the treatment of histoplasmosis. The encouraging response to its use in our first patient suggests that this form of sulphonamide combination is worth further trial.

In addition to specific antifungal agents, supportive measures may be required; in particular, corticosteroids to counter adrenocortical insufficiency. Though cortisone on its own was used for many years in two of our patients, such corticosteroid therapy without amphotericin cover may have serious consequences (Utz, 1968 ; Murray and Sladden, 1965).

We wish to thank Dr. John Graham for the culture reports and sensitivity results of the organism from case 1 . We are grateful to Dr. A. W. Spence for permission to publish details of case 2 and to Dr. Leslie McGee of Barking Hospital, Essex for the necropsy findings. We are also indebted to Dr. John Dadds of St. Mary's Hospital, Portsmouth for the clinical details of case 3, and to Dr. R. D. Clay and Dr. M. A. Rashid for the necropsy reports.

Sulfadoxine (Fanasil-Ro 4-4393) used in the initial treatment of case 1 was kindly supplied by Roche Products Limited through the courtesy of Dr. I. Lennox Smith.

We are indebted to the Wessex Regional Hospital Board for a contribution towards the cost of colour reproduction.

\section{REFERENCES}

Aldridge, M. J., Windsor, C. W. O., Ashton, F., Fawcett, F. J., and Whitby, J. L. (1970). Case of disseminated histoplasmosis. Brit. med. J., 4, 33.

Arblaster, P. G. (1950). Pulmonary histoplasmosis. Thorax, $5,333$.

Baker, R. D. (1968). In Systemic Mycoses. Ciba Foundation Symposium, edited by G. E. W. Wolstenholme and R. Porter, p. 13. J. and A. Churchill, London.

Bennett, D. E. (1967). Histoplasmosis of the oral cavity and larynx. Arch. intern. Med., 120, 417.

Crispell, K. R., Parson, W., Hamlin, J., and Hollifield, G. (1956). Addison's disease associated with histoplasmosis. Amer. J. Med., 20, 23.

Crofton, J. (1950). A probable case of pulmonary histoplasmosis diagnosed in England. Thorax, 5, 340.

Darling, S. T. (1906). A protozoon general infection producing pseudotubercles in the lungs and focal necroses in the liver, spleen and lymphnodes. J. Amer. med. Ass., 46, 1283.

(1908). Histoplasmosis: a fatal infectious disease resembling kala-azar found among natives of tropical America. Arch. intern. Med., 2, 107.

Derry, D. C. L., Card, W. I., and Wilson, R. (1942). Histoplasmosis of Darling. Report of a case. Lancet, 1, 224.
Duncan, J. T. (1945). A survey of fungus diseases in Great Britain. Results from the first eighteen months. Brit. med. J., 2, 715.

(1947). A unique form of histoplasma. Trans. roy. Soc. trop. Med. Hyg., 40, 364.

Earle, J. H. O., Highman, J. H., and Lockey, E. (1960). A case of disseminated histoplasmosis. Brit. med. J., 1, के 607.

Evans, P. (1949). Histoplasmosis. Lancet, 1, 368.

Furcolow, M. L. (1960). In Histoplasmosis, edited by H. C. Sweany, p. 400. Thomas, Springfield, Illinois.

Hewlett, T. H., Steer, A., and Thomas, D. E. (1966). Progressive fibrosing mediastinitis. Ann. thorac. Surg., 2, 345.

Hutchison, H. E. (1952). Laryngeal histoplasmosis simulating carcinoma. J. Path. Bact., 64, 309.

Kaplan, M. M., and Sherwood, L. M. (1963). Acute pericarditis due to Histoplasma capsulatum. Ann. intern. Med., 58, 862.

Klieger, H. L., and Fisher, E. R. (1962). Fibrocalcific constrictive pericarditis due to histoplasma capsulatum. New Engl. J. Med., 267, 593.

Knight, R. K. (1968). Histoplasmosis. Why not in Britain? Guy's Hosp. Rep., 117, 309.

Leigh, R., and Thomas, H. E. (1955). Benign histoplasmosis. Thorax, 10, 253.

Limerick, C. B. (1951). Histoplasmosis in England. Brit. med. J., 1, 885.

Locket, S., Atkinson, E. A., Grieve, W. S. M., and Bridson, E. (1953). Histoplasmosis in Great Britain. Description of a second case of disseminated histoplasmosis; treatment by ethyl vanillate. Brit. med. J., 2, 857.

Lucas, A. O. (1968). In Systemic Mycoses, Ciba Symposium, edited by G. E. W. Wolstenholme and R. Porter, p. 101. $\mathrm{J}$. and A. Churchill, London.

McCracken, B. H. (1948). Intra-pulmonary calcification and histoplasmin sensitivity. Thorax, 3, 45 .

Mason, A. S., Meade, T. W., Lee, J. A. H., and Morris, J. N. (1968). Epidemiological and clinical picture of Addison's 으 disease. Lancet, $2,744$.

Miller, A. A., Ramsden, F., and Geake, M. R. (1961). Acute disseminated histoplasmosis of pulmonary origin probably contracted in Britain. Thorax, 16, 388.

Murray, P. J. S., and Sladden, R. A. (1965). Disseminated histoplasmosis following long-term steroid therapy for reticulosarcoma. Brit. med. J., 2, 631.

Negroni P. (1964). Proceedings of the 2nd Conference on Contagious Diseases, Cordoba, Argentine, July.

Parsons, R. J., and Zarafonetis, C. J. D. (1945). Histoplasmosis in man. Report of seven cases and a review of seventy-one cases. Arch. intern. Med., 75, 1.

Partridge, B. M., and Tanser, A. R. (1966). Disseminated N histoplasmosis and its treatment. Postgrad. med.J., 42, N 568.

Poles, F. C., and Lavertine, J. D. O’D. (1954). Acute disseminated histoplasmosis with a report of a case occurring in 6 England. Thorax, 9, 233.

Rosenbaum, A. E., Schweppe, H. I., and Rabin, E. R. (1964). Constrictive pericarditis, pneumopericardium and aortic aneurysm due to histoplasma capsulatum. New Engl. J. T Med., 270, 935.

Sakula, A. (1953). A case of pulmonary histoplasmosis. Tubercle (Lond.), 34, 18.

Schub, H. M., Spivey, C. G., and Baird, G. D. (1966). Pleural involvement in histoplasmosis. Amer. Rev. resp.웅 Dis., 94, 225. 
Soper, R. T., Silber, D. L., and Holcomb, G. W. (1970). Gastrointestinal histoplasmosis in children. $J$. pediat. Surg., 5, 32.

Symmers, W. St. C. (1956a). Histoplasmosis contracted in Britain. A case of histoplasmic lymphadenitis following clinical recovery from sarcoidosis. Brit. med. J., 2, 786.

- (1956b). Localized cutaneous histoplasmosis. Brit. med.J., 2, 790.
(1960). In Recent Advances in Clinical Pathology, Series 3, edited by S. C. Dyke. Churchill, London.

Utz, J. P. (1968). In Systemic Mycoses. Ciba Symposium, edited by G. E. W. Wolstenholme and R. Porter, pp. 243 and 250. J. and A. Churchill, London.

Welsh, P., Coppola, F., and Capelli, L. (1969). Rupture of abdominal aorta by histoplasma capsulatum. $J$. cardiovasc. Surg., 10, 163. 